\title{
Derleme
}

\section{Ortodontik diş hareketini hızlandıran farmakolojik uygulamalar ve mekanik-fiziksel stimülasyonlar}

\author{
Gökhan Türker1, Gizem Akgün² \\ 1Mersin Üniversitesi Diş Hekimliği Fakültesi, Ortodonti AD, Mersin, Türkiye \\ Erciyes Üniversitesi Diş Hekimliği Fakültesi, Ortodonti AD, Kayseri, Türkiye
}

\section{Öz}

Dişlere kuvvet uygulanarak estetik ve fonksiyonel açıdan kabul edilebilir en iyi okluzyonu sağlamayı hedefleyen ortodontik tedaviler, genellikle uzun bir süreci içeren, zaman alıcı uygulamalardır. Tedavi süresinin uzun olması, hastaların tedaviye olan uyumlarının azalmasının yanında alveolar kemik rezorpsiyonu, kök rezorpsiyonu ve diş çürükleri gibi çeşitli istenmeyen etkilerin oluşmasına neden olabilmektedir. Bu istenmeyen etkilerin engellenmesi veya en aza indirgenmesi için diş hareketini hızlandırarak tedavi süresini kısaltmak amacıyla çeşitli yöntemler geliştirilmiştir. Bu yöntemler, cerrahi destekli uygulamalar, farmakolojik uygulamalar ve mekanik-fiziksel stimülasyonlar olmak üzere genel olarak üç ana başlıkta incelenmektedir. Bu derlemede, ortodontik diş hareketini hızlandırmak amacıyla uygulanan farmakolojik uygulamalar ve mekanik-fiziksel stimülasyonlar hakkında bilgiler sunulmuştur.

Anahtar Sözcükler: Diş hareketi, mekanik, farmakolojik

\section{Pharmacological applications and mechanical-physical stimulations to accelerating orthodontic tooth movement}

\begin{abstract}
Orthodontic treatments aiming in achieving the best acceptable aesthetic and functional occlusion by applying force to the teeth are time consuming applications, usually involving a long process. The over exceeding treatment time can lead to the reduction of patient compliances with treatment, as well as the formation of various side effects such as alveolar bone resorption, root resorption and caries. Various methods have been developed to reduce the treatment duration by accelerating tooth movement to prevent or minimize these side effects. These methods are generally investigated in three main areas as surgical-assisted applications, pharmacological applications, and mechanical-physical stimulation. In this review, information about pharmacological applications and mechanical-physical stimulations applied to accelerate the orthodontic tooth movement.
\end{abstract}

Keywords: Tooth movement, mechanical, pharmacological

Yazının geliş tarihi: 11.07.2017 Yazının kabul tarihi: 02.10.2017

Sorumlu yazar: Gökhan Türker, Mersin Üniversitesi Diş Hekimliği Fakültesi Ortodonti Anabilim Dalı, Çiftlikköy Kampüsü Yenişehir/Mersin, Tlf: $0324 \quad 361 \quad 00 \quad 37$, E-posta: gokhanturker532@hotmail.com 


\section{Giriş}

Çene-yüz sistemindeki iskeletsel ve dişsel bozuklukların tedavisi ile ilgilenen ortodontinin temel amacı, kabul edilebilir bir yüz estetiği ile birlikte stabil bir şekilde en iyi okluzal ilişkiyi sağlayabilmektir. Ortodontik tedaviler genellikle 1 ila 2 yl kadar bir sürede tamamlanırken, diş çekimini içeren daha karmaşık vakalarda ise tedavinin tamamlanması için daha fazla zaman gerekmekte ve bu uzun süreler nedeniyle birçok hasta ortodontik tedaviyi istememektedir.1,2 Ayrıca, uzun süreli ortodontik tedavilerin sonucunda, kötü oral hijyen nedeniyle meydana gelen diş çürükleri ve periodontal hastalıklar, hastaların uyum problemleri, alveol kemik rezorpsiyonları ve en önemlisi kök rezorpsiyonları meydana gelebilmektedir. ${ }^{3-5}$

Ortodontik tedavileri daha kısa sürede gerçekleştirebilmek için uygulanan ortodontik kuvvetin şiddetinin arttırılması, periodontal ligamentin basınç bölgesinde kan akımının durmasına sebep olmakta ve hücresel faaliyetlerde yavașlamaya neden olan hyalinizasyon dokusu oluşmaktadır. ${ }^{6} \mathrm{Bu}$ nedenle, ortodontik kuvvetin şiddeti artırılmadan, dişin hareketi esnasında çevresel faktörleri değiștirerek ve dokularda oluşan direnci azaltarak diş hareketini hızlandırmak, buna bağlı olarak da tedavi süresini kısaltmak amaciyla son yıllarda çeşitli cerrahi uygulamalar, farmakolojik uygulamalar ve mekanik-fiziksel stimülasyonlar kullanılmaktadır.

Diş hareketini hızlandıran cerrahi destekli yöntemler diğer yöntemlere göre daha invazivdirler ve cerrahi ișlemlere bağlı olarak bakteriyemi gibi riskler mevcuttur.7, 8 Yapılan uygulamaların hastalar tarafından daha kabul edilebilir ve daha konservatif olmaları nedeniyle derlememizde diș hareketini hızlandırmak amacıyla kullanılan farmakolojik uygulamalar ve mekanikfiziksel stimülasyonlar hakkında literatür bilgisi verilmiştir.

\section{Farmakolojik Uygulamalar}

Ortodontik diş hareketi sırasında uygulanan kuvvete karşı dokularda meydana gelen direnci azaltmak, çevresel faktörleri değiştirmek ve sonuçta diş hareketini hızlandırarak tedavi süresini kısaltmak amaciyla sitokinler, prostaglandinler, osteokalsin, nitrik oksit, lökotrienler, vasküler endotelyal büyüme faktörü, trombositten zengin plazma gibi mekanik kuvvetleri hücresel cevaba dönüştüren fizyolojik aracılar kullanılmıştır.9-21 Ayrıca kortikosteroidler, paratiroid hormonu, 1,25dihidroksikolekalsiferol ve relaksin gibi sistemik faktörlerin de diş hareketini hızlandırdığı literatürde bildirilmiştir. ${ }^{22-30}$

\section{Fizyolojik Aracı Uygulamaları}

Diş üzerine ortodontik kuvvet uygulanmasını takiben, basınç ve gerilim kuvvetlerinin etkisinde kalan periodontal dokularda prostaglandinlerin, nöropeptitlerin, nörotransmitterlerin, lökotrienlerin ve sitokinlerin seviyelerinde bir artış görülmektedir.10,11

Hücre dıșı sinyal proteini olan sitokinler, ortodontik diș hareketini kolaylaştıran iki anahtar olay olan inflamatuar reaksiyonlarda ve kemik remodelinginde doğrudan yer alırlar, aynı zamanda periodontal ligamentte hücre farklılaşmasını, aktivasyonunu ve apoptozisini kolaylaştırırlar. Bu olaylar diş hareketi sırasında interlökinler ve tümör nekroz faktör-alfa (TNF- $\alpha$ ) gibi sitokin seviyelerinin artışı ile olmaktadır. İnterlökinlerin etkileri, osteoklastların farklılaşmasını kolaylaştıran prostaglandin E2 (PGE2) ve makrofaj koloni uyarıcı faktör (M-CSF) üretiminin artırılmasına aracilık etmektedir. Alveolar kemik rezorbsiyonunda en önemli işlemlerden biri olan osteoklastogenezis genelde nükleer faktör kappa B ligand (RANKL) reseptör aktivatörü ve M-CSF tarafından düzenlenmektedir. ${ }^{31}$

Kanzaki ve ark. ${ }^{12}$, yaptıkları deneysel çalışmada diş hareketi sırasında periodontal dokulara lokal RANKL geni transfer etmişler ve herhangi bir sistemik yan etki olmadan, RANKL'ın sağladığı osteoklastogenezis sayesinde ortodontik diş hareket hızında bir artış sağlamışlardır, ayrıca bu uygulama ile hem ortodontik tedavi süresinin kısaltılabileceğini hem de ankiloze bir dişin hareket ettirilebileceğini bildirmişlerdir. Son yıllarda, IIglesias-Linares ve ark. ${ }^{13}$ diş hareketini hızlandırma etkisini 
değerlendirmek amacıyla RANKL geni transferi ve kortikotomiyi karşılaştırmış, sonuç olarak diş hareketini hızlandırmak için RANKL geni transferinin kortikotomi uygulamasina kıyasla daha etkili olabileceğini rapor etmişlerdir.

Brooks ve ark. ${ }^{14}$ pre-osteoklastların osteoklastlara farklılaşmasında önemli bir rol oynadığını göstermek ve diş hareketini hızlandırmak amacıyla deneysel olarak erkek farelere lokal M-CSF enjeksiyonu yapmışlar ve diş hareket hızında \%14 oranında bir artış olduğunu göstermişlerdir.

Prostaglandinler, özellikle de PGE2 kemik metabolizmasının kuvvetli ve çok fonksiyonlu düzenleyicileridir. ${ }^{32}$ PGE2 kemik iliği içinde bulunan osteoklast formasyonuna etki etmesinin yanı sıra direkt olarak osteoblast öncü hücrelerini etkileyerek osteoblastik farklılașma üzerinde de etkin bir rol oynar.33 Kemik rezorbsiyonu ve apozisyonu üzerine PGE2'nin etkilerinin belirlenmesi, araştırıcıların diş hareketi esnasında prostaglandinlerin rolü üzerine birçok araştırma yapılmasına sebep olmuştur. Bu konuda yapılan birçok çalışma prostaglandinin hem sistemik hem de lokal uygulamasının diş hareketini hızlandırdığını ortaya koymuștur.9, 10, 15, 16

Yamasaki ve ark. ${ }^{10}$ yaptıkları klinik çalışmada, kanin distalizasyonu sırasında PGE1'i kanin dişin distaline submukozal olarak enjekte etmiş ve deney grubunda kanin dişin 2 kat daha hızlı hareket ettiğini rapor etmişlerdir, ayrıca bu ișlemin hafif bir ağrı dışında hiçbir yan etki oluşturmadığını bildirmişlerdir.

Leiker ve ark. ${ }^{15}$ PGE2 uygulama sayısının ve dozunun ortodontik diş hareketi üzerine etkilerini inceledikleri çalışmada düşük konsantrasyonlu uygulamaların, yüksek konsantrasyonlu uygulamalardan daha etkili olduğunu, tek doz uygulama ile çok sayıda uygulama arasında önemli bir fark olmadığını, ayrıca yüksek konsantrasyon ve çok sayıda enjeksiyonun kök rezorpsiyonunu artırabileceğini bildirmişlerdir.

Seifi ve $\operatorname{ark}^{9}$ ratlar üzerinde yaptıkları çalışmada submukozal PGE2 ve intraperitonal kalsiyum glukonatın birlikte uygulanmasının ortodontik diş hareketi ve kök rezorpsiyonu üzerine etkilerini incelemişler ve sonuç olarak PGE2+kalsiyum glukonat uygulamasının ortodontik diş hareket hızını artırdığını ve kök rezorpsiyonunu durdurduğunu bildirmişlerdir.

Prostaglandinler ile ilgili 2015 yılında yaptıkları deneysel çalışmada Seifi ve ark. ${ }^{16}$ PGE2, kalsiyum ve tiroid hormonu uygulamalarının ayrı ayrı ve çeşitli kombinasyonlarda birlikte uygulamalarının diş hareket hızı ve kök rezorpsiyonu üzerine etkilerini incelemişler, sonuçta tiroksin+PGE2 kombinasyonunun sinerjistik etki göstererek diş hareketini hızlandırdığını ve kök rezorpsiyonunu azalttığını bildirmişlerdir.

Osteokalsin, osteoblastlar tarafından sentezlenen, normal kemik mineralizasyonunun sağlanmasında gerekli olan ve kalsiyum metabolizmasını düzenleyen hormonlar (kalsitonin, paratiroid hormonu, vitamin D) tarafindan direkt olarak etkilenen bir matriks proteinidir. ${ }^{34}$ Hashimoto ve ark. ${ }^{17}$, osteokalsinin diş hareket hızına etkisini inceledikleri deneysel çalışmada, lokal osteokalsin enjeksiyonu sonrasinda 10 günlük bir süre boyunca diş hareketini histolojik olarak değerlendirmiş ve osteokalsinin lokal olarak uygulanmasının diş hareketini hızlandırdığını bildirmişlerdir.

Pek çok fizyolojik ve patolojik olayda anahtar rol oynayan nitrik oksit, kemik yapım ve yıkım döngüsünde belirleyici bir faktördür. ${ }^{35}$ Ortodontik kuvvet uygulanması ile gingival dokularda nitrik oksit sentaz enzim düzeyi artmaktadır. ${ }^{36}$ Nitrik oksit enjeksiyonu ile osteoklastlarda, kapiller damarlanmada ve ortodontik diş hareketinde belirgin artış olduğu deneysel olarak gösterilmiștir. ${ }^{18}$

Kuvvetli bir anjiyogenezis uyarıcısı olan ve kemik iyileşme bölgesindeki osteoblastlar, osteoklastlar ve mezenkimal hücrelerden yoğun olarak salınan vasküler endotelyal büyüme faktörü (VEGF), yeni damar oluşumunu artırarak kemik iyileşmesine katkı sağlamaktadır. ${ }^{37}$ Diş hareket hızı üzerine VEGF'nin etkilerini incelemek amaciyla yapılan deneysel 
çalışmalarda lokal VEGF uygulamasının kemik remodelingini artırarak diş hareketinin hızlanmasını sağladığı ve antiVEGF poliklonal antikorun lokal enjeksiyonu ile diş hareket hızının azaldığı gösterilmiştir. 19, 38

Plazmanın küçük bir hacminde yer alan trombositlerin otolog bir konsantrasyonu olarak tanımlanan trombositten zengin plazma (TZP)'nın zengin bir otolog büyüme faktörü ve sitokin kaynağı olduğu düşünülmektedir.20,21 Yapılan çeşitli çalışmalarda yüksek düzeyde uygulanan TZP'nin kemik hücrelerinin bölünmesini inhibe ettiği ve kemik yoğunluğunu azalttığı görülmüș ve bu nedenle ortodontik diş hareketinin bu uygulama ile hızlandırılabileceği düşünülmüştür. 20, 39, 40

Güleç ve ark.20 ratlar üzerinde yaptıkları deneysel çalışmada orta ve yüksek düzeyde uygulama yapılan iki deney grubunda TZP'yi hayvanların să̆ üst çenesinde yer alan birinci molar dişlerinin mezial köklerinin bulunduğu bölgeye enjekte etmişlerdir. $\mathrm{Bu}$ çalışmanın sonucunda, yüksek düzeyde uygulanan TZP'nin osteoklastik aktiviteyi geçici olarak güçlendirerek diş hareketini hızlandırabileceği ve orta düzeyde uygulamanın da yüksek düzeyden daha az olmakla birlikte diş hareketini hızlandırabileceği bildirilmiștir.

Rashid ve ark. ${ }^{21}$, köpekler üzerinde yaptıkları ve 2017 yılında yayınlanan çalışmalarında, lokal TZP enjeksiyonu yapılarak belirgin bir klinik ve mikroskobik yan etki görülmeden diş hareketinin hızlandırılabileceğini belirtmişlerdir.

\section{Sistemik Faktör Uygulamaları}

Kortikosteroidler, kemiğin apozisyon ve rezorpsiyon döngüsünde rezorpsiyonu artırıcl, apozisyonu ise azaltıcı yönde etkilerler ve hatta kortikosteroidlerin düşük dozlarda osteoblastlar üzerine direkt etkileri vardır. ${ }^{41}$ Kortikosteroidlerin diş hareket hızı ve kök rezorpsiyonu üzerine etkileriyle ilgili yapılan çalışmalarda doza bağlı olarak farklı sonuçlar gösterilmiştir.22, 23

Ong ve ark. $^{22}$ ratlara $1 \mathrm{mg} / \mathrm{kg}$ dozunda kortikosteroid türevi olan prednisol uyguladıkları çalışmanın sonuçlarında diș hareket hızında anlamlı bir değişiklik olmadığını ancak tedavi grubunda kök rezorpsiyonunun daha az olduğunu bildirmişlerdir.

Ashcraft ve ark. ${ }^{23}$ diş hareket hızı üzerine kortikosteroidlerin etkisini inceledikleri çalışmalarında, tavşanlara 15 $\mathrm{mg} / \mathrm{kg}$ dozunda kortizon asetat verdikleri deney grubunda, kontrol grubuna göre 4 kat daha fazla diş hareketi olduğunu ve aktif diş hareketi sonrasında alınan kesitlerde kemik rezorpsiyon alanlarının daha fazla olduğunu bildirmişlerdir.

Son zamanlarda yapılan deneysel bir çalışmada sentetik bir kortikosteroid olan triamnisolon asetonid tavşanlara kas içi enjeksiyon yapılarak günde $1 \mathrm{mg} / \mathrm{kg}$ dozunda 21 gün boyunca uygulanmış ve bu uygulama ile ortodontik diş hareketinde belirgin bir artış olduğu rapor edilmiştir. ${ }^{24}$

Kortikosteroid uygulamaları dışında, paratiroid hormon ve D vitaminin aktif formu olan 1,25-dihidroksikolekalsiferol gibi sistemik faktörlerin de diş hareket hızı üzerine etkileri literatürde incelenmiştir.25-29 Paratiroid hormon, kalsitonin ve 1,25dihidroksikolekalsiferol hormonları birlikte vücutta kalsiyum dengesinin düzenlemesinden sorumlu hormonlardır. Paratiroid hormon serum kalsiyum miktarını yükseltip, fosfat miktarını düşürürken, kalsitonin serum kalsiyum ve fosfat miktarının düşmesini, D vitamini metabolitleri ise hem kalsiyum hem de fosfat miktarının yükselmesini sağlamaktadır. Söz konusu hormonlar bu düzenlemeyi birbirleri ile karmaşık bir șekilde etkileşerek ve böylece birbirlerinin etkilerini tamamlayarak bütünleşmiş bir biçimde yapmaktadırlar. ${ }^{42}$ Yapılan çalıșmalarda paratiroid hormon ve 1,25dihidroksikolekalsiferol uygulamalarının diş hareket hızını artırdığı gösterilmiştir. 25-29

Kale ve ark. ${ }^{28}$ lokal olarak uygulanan 1,25-dihidroksikolekalsiferol ve PGE2'nin ortodontik diş hareketi üzerindeki etkilerini histolojik parametreler kullanılarak değerlendirdikleri çalışmanın sonucunda, her iki uygulamanın da herhangi bir yan etki oluşturmadan diş hareket miktarını artırdığını, ancak uygulamaların etkinliğinin 
diş hareket hızı üzerinde benzer olduğunu bildirmişlerdir.

Ana görevi fibröz bağ dokuların turnoverını artırmak olan ve hem kadınlarda hem de erkeklerde bulunan bir hormon olan relaksinin periodontal ligament üzerinde oluşturacağ ${ }_{1}$ etki ile ortodontik diș hareketini hızlandırabileceği düşünülmüştür. ${ }^{30} \mathrm{Bu}$ düşüncenin aksine, Madan ve ark. ${ }^{43}$ insan relaksin hormonu ile ratlarda yaptıkları çalışmada, bu hormonun ortodontik diş hareket hızına etki etmediğini, periodontal ligament organizasyonunu ve mekanik dayanıklılığını azalttığını ve diş mobilitesini artırdığını göstermişlerdir. Liu ve ark. $^{30}$ ise insan relaksin hormonunu ratlarda uygulamış ve sonuçta bu uygulama ile erken safhada diş hareketinin hızlandırılabileceğini belirtmiştir. McGorray ve ark. ${ }^{44}$ randomize plasebo kontrollü klinik çalışmalarında 8 haftalık süreçte haftada bir lokal olarak uygulanan $50 \mu \mathrm{g}$ relaksinin diş hareket hızını etkilemediğini bildirmişlerdir.

\section{Mekanik-Fiziksel Stimülasyonlar}

\section{Doğrudan Elektrik Akımları ve} Elektromanyetik Stimülasyon

$\begin{array}{ccr}\text { Elektrik akımlarının } & \text { kemik } \\ \text { metabolizması üzerine etkilerinin }\end{array}$
incelendiği ilk çalışmalarda, araştırmacılar, elektrik akımı ile birlikte, hücrelerin organellerinde kemik remodelingini etkileyen bir takım değişiklikler gözlemlemişlerdir.45, 46 15-20 mikroamper düzeyinde uygulanan doğru akımın kemiğin hücre membranı etrafındaki elektrolit akımını değiştirerek diş hareketini hızlandırdığı bildirilmiştir. ${ }^{47}$

Elektromanyetik alan uygulamaları, periodontal aralıkta hücresel faaliyetleri etkileyerek hem osteoklastik hem de osteoblastik aktiviteyi hızlandırmaktadır ve artan osteogenezise bağlı olarak da diş hareketi hızını artırabilmektedir. ${ }^{48}$

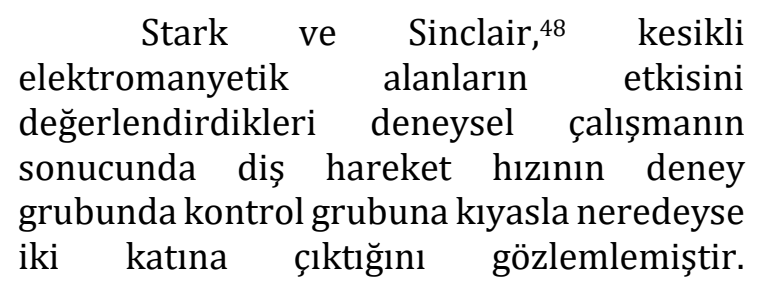

Mıknatıslarla kesikli elektromanyetik alanlar üreterek diş hareket hızının artırıldığı daha sonra yapılan çalışmalarla da teyit edilmiştir. ${ }^{49}, 50$

Spadari ve ark.51 2017 yılında yayınlanan deneysel çalışmalarında ratların ortodontik olarak hareket ettirilecek dişlerine günde 5 dakika 10 mikroamper düzeyinde elektrik akımı uygulanarak doku yanitının artırıldığını ve bu uygulama ile hızlı ve güvenilir bir şekilde diş hareketinin elde edilebileceğini bildirmişlerdir.

\section{Titreşim Uygulamaları}

Titreşim stimulusu kullanarak diş hareketini hızlandırmak için ilk çabalar Krishtab ve ark. ${ }^{52}$ tarafından gösterilmiștir. Bunu takiben Ohmae ve ark. ${ }^{53}$ başarılı bir şekilde ultrasonik titreșimle diş hareket hızını artırmışlar, fakat ultrasonik titreşimin diş pulpası üzerine zararlı etkiler sergilediğini bildirmişlerdir.

Nishimura ve ark. ${ }^{54}$ titreşim uygulayan bir sistem geliştirerek yaptıkları deneysel çalışmada rezonans titreşim ile diş hareketinde, osteoklast sayısında ve RANKL ekspresyonunda artış gözlemlemişler ve histolojik olarak kontrol grubu ile deney grubu arasında kök rezorpsiyon miktarında anlamlı bir fark olmadığını belirtmişlerdir.

Miles ve ark. $^{55}$ tarafindan yapılan klinik çalışmada ise, hastalara sabit aparey tedavisi ile birlikte günde en az 20 dakika boyunca titreşim apareyi uygulamaları söylenmiş ve 10 haftalık çalışma süresince, deney grubunda çapraşıklıkta \%65'lik azalma gözlenirken, kontrol grubunda bu oran $\% 69$ olarak bulunmuștur.

Leethanakul ve ark. ${ }^{56}$ üst birinci premolar çekimli vakalarda kanin distalizasyonu sırasında hafif ortodontik kuvvete (60gr) ek olarak hastalara sadece tek taraftaki kanin dişlerine elektrikli diş firçası ile 2 ay boyunca günde 3 defa 15 'er dakika titreşim uygulamalarını söylemiş ve sonuçta interlökin $1 \beta$ (IL-1 $\beta$ ) sekresyonunun ve diş hareket miktarının elektrikli diş fırçası kullanılan tarafta anlamlı derecede fazla olduğunu bildirmişlerdir.

Son olarak 2017 yılında Liao ve ark. ${ }^{57}$ yaptıkları klinik çalışmada kanin distalizasyonu sırasında 150 gr ortodontik 
kuvvet uygulanan dişlerin bukkal yüzeyinden $50 \mathrm{~Hz}$ frekansinda ve $20 \mathrm{gr}$ büyüklügünde titreşim uygulayarak daha hızlı diş hareketi elde ettiklerini rapor etmişlerdir.

\section{Düşük Doz Lazer Uygulamaları}

Lazer işınlarının dokuda en fazla $1^{\circ} \mathrm{C}^{\prime}$ lik ISı artışı yaratarak oluşturduğu etkilere biyostimülan etkiler, lazer ışınlarının biyostimülan etkilerinden faydalanılarak yapılan tedaviye düșük doz lazer tedavisi (DDLT) denilmektedir.58 Düşük doz lazer ışınlaması elektron transferinde sitokrom C oksidaz enzimini aktive ederek hücre içi adenozin trifosfat (ATP) üretimini artırmaktadır ve biyostimülasyon etkisinin ATP artışına bağlı olarak meydana gelen hücresel aktivite artışına bağlı olduğu düşünülmektedir. ${ }^{59}$

Ortodonti alanında DDLT uygulaması ile oluşturulan bu biyostimülan etkiler ortodontik tedaviye bağlı oluşan ağrının giderilmesinde, kemik formasyonunun artırılmasında, kök rezorpsiyonunun önlenmesinde, ortognatik cerrahi sonrası iyileșmenin hızlandırılmasında ve diş hareketinin hizlandırılmasinda kullanılmaktadır. 58

Diş hareket hızı üzerine DDLT’nin etkisinin ilk kez incelendiği deneysel çalışmada Kawasaki ve Shimizu60 deney hayvanlarının molar dişlerine $10 \mathrm{gr}$ ortodontik kuvvet uygulamanın yanında 12 gün boyunca 3 ayrı bölgede (bukkal, palatal, mezial) günde toplam 9 dakika $35,3 \mathrm{~W} / \mathrm{cm}^{2}$ (54 Joule) $830 \mathrm{~nm}$ dalga boyunda diyot lazer uygulamışlardır. Yapılan histomorfometrik ve histolojik analizler sonucunda, lazer uygulamasıyla kemik remodelinginde artış ve diş hareketinde 1,3 kat hızlanma olduğunu bildirmişlerdir.

Cruz ve ark.61 DDLT'nin diş hareketi üzerindeki etkisine yönelik ilk klinik çalışmayı yapmış ve kanin distalizasyonu sirasinda her kuvvet aktivasyonu sonrasında $780 \mathrm{~nm}$ gücünde ve $5 \mathrm{~J} / \mathrm{cm}^{2}$ dozunda diyot lazer uygulamışlardır. İki aylık aktivasyon sonrasinda, lazer uygulanan segmentte $\% 34$ oranında daha hizlı kanin distalizasyonu gözlemlemişler ve düşük enerjili lazer kullanımıyla, tedavi süresinde, hasta rahatsızlığında ve ağrı duyusunda ciddi azalma saptamışlardır.

Daha sonra yapılan çeşitli deneysel ve klinik çalışmada farklı dalga boylarına sahip diyot lazerler kullanılarak farklı dozlarda uygulamalar yapılmış ve çalışmacıların bir kısmı DDLT'nin diş hareket hızı üzerine olumlu etkileri olduğundan bahsetmiştir. ${ }^{62-64}$

$\mathrm{Bu}$ sonuçların aksine, Limpanichkul ve ark. $^{65}$ klinik çalıșmalarında kanin distalizasyonu sırasında her aktivasyonda ve 2 gün sonrasında, $860 \mathrm{~nm}$ gücünde ve 25 $\mathrm{J} / \mathrm{cm}^{2}$ dozuyla toplam 23 saniye süreyle diyot lazer uygulamışlar, sonuçta DDLT'nin diş hareket hızını etkilemediğini bildirmiş ve diş hareketini stimüle etmek amacıyla kullanılması gereken lazer dozunu, tartışma konusu olarak ortaya atmışlardır.

Goulart ve ark. ${ }^{66} 5,25 \mathrm{~J} / \mathrm{cm}^{2}$ ve 35,0 $\mathrm{J} / \mathrm{cm}^{2}$ lik iki dozda $780 \mathrm{~nm}$ dalga boyuna sahip diyot lazer kullanarak yaptıkları deneysel çalışmanın sonucunda $5,25 \mathrm{~J} / \mathrm{cm}^{2}$ lazer uygulanan grupta diş hareketinin hızlandığını; 35,0 J/ $\mathrm{cm}^{2}$ lazer uygulanan grupta diş hareketinin yavaşladığını bildirmişlerdir.

Ge ve ark. ${ }^{5} 2015$ yılında yaptıkları sistematik derleme ve meta-analiz'de DDLT uygulaması ile diş hareketinin hızlandırılabileceğini, bu hızlandırma etkisinin alt ve üst çeneler arasında istatistiksel olarak farklılık göstermediğini ve optimum doz henüz belirlenememiş olmasına rağmen diş hareket hızının artırılmasında nispeten daha düşük $(2,5,5$ ve $8 \mathrm{~J} / \mathrm{cm}^{2}$ ) enerji yoğunluğuna sahip lazer kullanımının, $20 \mathrm{~J} / \mathrm{cm}^{2}, 25 \mathrm{~J} / \mathrm{cm}^{2}$ ye ve daha yüksek olanlara göre daha etkili olduğunu bildirmişlerdir.

Almeida ve ark.67 DDLT uygulamasının diş hareketi üzerine etkisini değerlendirdikleri sistematik derleme ve meta-analizlerinin sonucunda lazer tedavisinin diş hareketini hızlandırabileceğine dair herhangi bir kanıt bulunamadığı ve DDLT'nin diş hareket hızı üzerine etkilerini değerlendirmek amacıyla daha büyük örneklem grubuna sahip randomize-kontrollü klinik çalışmalara 
ihtiyaç olduğu ş̧eklinde görüş bildirmişlerdir.

Sonesson ve ark.68 ise 2016 yllında yaptıkları sistematik derlemede DDLT'nin ortodontik diş hareketini hızlandırma, relapsı önleme ve akut ağrıyı yönetme üzerine etkilerini değerlendirmişler, sonuç olarak bu uygulamanın diş hareketini hızlandırdığına dair çok düşük kalitede, akut ağrıyı yönetmekte etkili olduğuna dair ise düşük kalitede kanıt olduğunu rapor etmişlerdir.

\section{Fotobiyomodülasyon}

Düşük yoğunlukta ışık yayan diyot (LED) ile yapılan fotobiyomodülasyon uygulamalarının özellikle iskemik ve yaralanmış hücrelerde, hücre içi ATP üretimini uyararak yara iyileșmesini hızlandırdığı kanıtlanmış ve bu etki LED uygulamasına bağlı olarak hücre içi ATP üretiminin artmasına, hücrede metabolik olarak optimum koşulların ve daha normal hücre fonksiyonlarının oluşmasına bağlanmıştır. ${ }^{69}$

\section{Son}

zamanlarda, fotobiyomodülasyon uygulaması ile diş hareketini hızlandırma açısından başarıyla sonuçlanan araştırmalar yayınlanmıştır. Ekizer ve ark. $^{70}$ ratlara $618 \mathrm{~nm}$ dalga boyunda ve $20 \mathrm{~mW} / \mathrm{cm}^{2}$ çıkış gücünde LED cihazı kullanarak fotobiyomodülasyon tedavisi uygulamış, sonuçlar kontrol grubuyla karşılaştırıldığında deney grubunda daha fazla diş hareketi olduğunu ve deney grubunda kök rezorpsiyonunun daha az miktarda olduğunu bildirmişlerdir.

Kau ve ark. ${ }^{71}$ kızılötesi sşığa yakın $850 \mathrm{~nm}$ dalga boylu endüstriyel standartl LED'i 90 hastada uygulamış ve bu uygulamada yanak yüzeyi, sırasıyla, 72, 108, ve $216 \mathrm{~J} / \mathrm{cm}^{2}$ toplam enerji yoğunluğu elde etmek için 20 dakika/gün, 30 dakika/gün ve 60 dakika/hafta olacak şekilde 60 $\mathrm{mW} / \mathrm{cm}^{2}$ lik bir güç yoğunluğu ile ışınlanmıştır. Çalışmanın sonucunda kontrol grubuna oranla deney grubunda çapraşıklığın daha hızlı düzeldiği gözlemlenmiştir.

Ekizer ve ark. ${ }^{72} 2016$ yılında 20 hasta üzerinde yaptıkları randomize kontrollü klinik çalışmada LED uygulamasının minivida stabilitesi ve diş hareket hızı üzerine etkilerini incelemişler ve kanin distalizasyonunun ilk 21 gününde hastaların çalışma grubuna dahil edilen kanin dişlerinin olduğu üst yarım çenelerine $618 \mathrm{~nm}$ dalga boyunda ve $20 \mathrm{~mW} / \mathrm{cm}^{2}$ çıkış gücünde LED cihazı ile yanak derisi üzerinden fotobiyomodülasyon tedavisi uygulamışlardır. Bu çalışmanın sonucunda, LED aracilı fotobiyomodülasyon tedavisinin diş hareket hızını artırdığı ve minividaların stabilitesini olumlu yönde etkilediği bildirilmiștir. ${ }^{72}$

$$
\text { Yakın geçmişte yapılan }
$$
fotobiyomodülasyon uygulamasının alt anterior bölgedeki çapraşıklığın çözülmesi sırasında diş hareket hızı üzerine etkisini değerlendiren bir klinik çalışmanın sonucunda $850 \mathrm{~nm}$ dalga boyunda ve 90 $\mathrm{mW} / \mathrm{cm}^{2}$ çıkış gücünde LED cihazı ile yapılan bu uygulamanın çapraşıklığın çözülmesini hızlandırabileceği rapor edilmiştir. ${ }^{73}$

\section{Sonuç}

Günümüzde ortodontik diş hareketinin dişlere ve dişleri destekleyen dokulara zarar vermeden hızlandirılması amacıyla kullanılan birçok yöntem olduğu görülmektedir. Yapılan klinik ve deneysel çalışmalar göz önünde bulundurulduğunda Düşük Doz Lazer uygulamaları, Titreşim uygulamaları ve Fotobiyomodülasyon gibi fiziksel-mekanik stimülasyonların klinik olarak uygulanabilirliğinin daha fazla olduğu düşünülmektedir. Ortodontik diş hareketini hızlandırmak için kullanılan farmakolojik uygulamalar ve fiziksel-mekanik stimülasyonlar göz önünde bulundurulduğunda bu uygulamaların daha ileri çalışmalar yapılarak klinik açıdan daha fazla fayda sağlayacak şekilde geliştirilebileceği uygulamacılar tarafından değerlendirilmelidir.

\section{Kaynaklar}

1.Ren A., Lv T., Kang N., Zhao B., Chen Y., Bai D. Rapid orthodontic tooth movement aided by alveolar surgery in beagles. Am J Orthod Dentofacial Orthop 2007;131(2):160. 
2. Buschang P.H., Campbell P.M., Ruso S. Accelerating tooth movement with corticotomies: is it possible and desirable? Semin Orthod 2012;18(4):286-294.

3. Kurol J., Owman-Moll P., Lundgren D. Time-related root resorption after application of acontrolled continuous orthodontic force. Am J Orthod Dentofacial Orthop 1996;110(3):303-310.

4. Ristic M., Svabic M.V., Sasic M., Zelic O. Clinical and microbiological effects of fixed orthodontic appliances on periodontal tissues in adolescents. Orthod Craniofac Res 2007;10(4):187-195.

5. Ge M.K., He W.L., Chen J., Wen C., Yin X., Hu Z.A., Liu Z.P., Zou S.J. Efficacy of low-level laser therapy for accelerating tooth movement during orthodontic treatment: a systematic review and meta-analysis. Lasers Med Sci 2015;30(5):1609-1618.

6. Engström C., Granström G., Thilander B. Effect of orthodontic force on periodontal tissue metabolism a histologic and biochemical study in normal and hypocalcemic young rats. Am J Orthod Dentofacial Orthop 1988;93(6):486-495.

7. Nimeri G., Kau C.H., Abou-Kheir N.S., Corona R. Acceleration of tooth movement during orthodontic treatment-a frontier in orthodontics. Prog Orthod 2013;14(1):42.

8. Ileri Z., Akin M., Erdur E.A., Dagi H.T., Findik D. Bacteremia after piezocision. Am J Orthod Dentofac Orthop 2014;146(4):430436.

9. Seifi M., Eslami B., Saffar A.S. The effect of prostaglandin E2 and calcium gluconate on orthodontic tooth movement and root resorption in rats. Eur $J$ Orthod 2003;25(2):199-204.

10. Yamasaki K., Shibata Y., Imai S., Tani Y., Shibasaki Y., Fukuhara T. Clinical application of prostaglandin E 1 (PGE 1) upon orthodontic tooth movement. Am J Orthod 1984;85(6):508-518.

11. Mohammed A.H., Tatakis D.N., Dziak R. Leukotrienes in orthodontic tooth movement. Am J Orthod Dentofacial Orthop 1989;95(3):231-237.

12. Kanzaki H., Chiba M., Arai K., Takahashi I., Haruyama N., Nishimura M., Mitani H. Local RANKL gene transfer to the periodontal tissue accelerates orthodontic tooth movement. Gene Therapy 2006;13(8):678685.
13. Iglesias-Linares A., Moreno-Fernandez A.M., Yañez-Vico R., Mendoza-Mendoza A., Gonzalez-Moles M., Solano-Reina E. The use of gene therapy vs. corticotomy surgery in accelerating orthodontic tooth movement. Orthod Craniofacial Res 2011;14(3):138-148. 14. Brooks P.J., Heckler A.F., Wei K., Gong S.G. M-CSF accelerates orthodontic tooth movement by targeting preosteoclasts in mice. Angle Orthod 2011;81(2):277-283.

15. Leiker B.J., Nanda R.S., Currier G.F., Howes R.I., Sinha P.K. The effects of exogenous prostaglandins on orthodontic tooth movement in rats. Am J Orthod Dentofacial Orthop 1995;108(4):380-388.

16. Seifi M., Hamedi R., Khavandegar Z. The effect of thyroid hormone, prostaglandin E2, and calcium gluconate on orthodontic tooth movement and root resorption in rats. J Dent (Shiraz) 2015;16:35-42.

17. Hashimoto F., Kobayashi Y., Mataki S., Kobayashi K., Kato Y., Sakai H. Administration of osteocalcin accelerates orthodontic tooth movement induced by a closed coil spring in rats. Eur J Orthod 2001;23(5):535-545.

18. Akın E., Gurton A.U., Ölmez H. Effects of nitric oxide in orthodontic tooth movement in rats. Am J Orthod Dentofacial Orthop 2004;126(5):608-614.

19. Kaku M., Kohno S., Kawata T., Fujita T., Tokimasa C., Tsutsui K., Tanne K. Effects of vascular endothelial growth factor on osteoclast induction during tooth movement in mice. J Dent Res 2001;80(10):1880-1883. 20. Güleç A., Bakkalbaşı B.Ç., Cumbul A., Uslu Ü., Alev B., Yarat A. Effects of local plateletrich plasma injection on the rate of orthodontic tooth movement in a rat model: A histomorphometric study. Am J Orthod Dentofacial Orthop 2017;151(1):92-104.

21. Rashid A., ElSharaby F.A., Nassef E.M., Mehanni S., Mostafa Y.A. Effect of plateletrich plasma on orthodontic tooth movement in dogs. Orthod Craniofacial Res 2017;20(2):102-110.

22. Ong C.K., Walsh L.J., Harbrow D., Taverne A.A., Symons A.L. Orthodontic tooth movement in the prednisolone-treated rat. Angle Orthod 2000;70(2):118-125.

23. Ashcraft M.B., Southard K.A., Tolley E.A. The effect of corticosteroid-induced osteoporosis on orthodontic tooth 
movement. Am J Orthod Dentofacial Orthop 1992;102(4):310-319.

24. Abtahi M., Shafaee H., Saghravania N., Peel S, Giddon D, Sohrabi K. Effect of corticosteroids on orthodontic tooth movement in a rabbit model. J Clin Pediatr Dent 2014;38(3):285-289.

25. Goldie R.S., King G.J. Root resorption and tooth movement in orthodontically treated, calcium-deficient, and lactating rats. $\mathrm{Am} \mathrm{J}$ Orthod 1984;85(5):424-430.

26. Gianelly A.A., Schnur R.M. The use of parathyroid hormone to assist orthodontic tooth movement. Am J Orthod 1969;55(3):305.

27. Takano-Yamamoto T., Kawakami M., Yamashiro T. Effect of age on the rate of tooth movement in combination with local use of 1 , $25(\mathrm{OH}) 2 \mathrm{D} 3$ and mechanical force in the rat. J Dent Res 1992;71(8):1487-1492.

28. Kale S., Kocadereli I., Atilla P., Aşan E. Comparison of the effects of 1,25 dihydroxycholecalciferol and prostaglandin E 2 on orthodontic tooth movement. Am J Orthod Dentofacial Orthop 2004;125(5):607614.

29. Collins M.K., Sinclair P.M. The local use of vitamin $\mathrm{D}$ to increase the rate of orthodontic tooth movement. Am J Orthod Dentofacial Orthop 1988;94(4):278-284.

30. Liu Z.J., King G.J., Gu G.M., Shin J.Y., Stewart D.R. Does human relaxin accelerate orthodontic tooth movement in rats? Ann NY Acad Sci 2005;1041(1):388-394.

31. Krishnan V., Davidovitch Ze. Cellular, molecular, and tissue-level reactions to orthodontic force. Am J Orthod Dentofacial Orthop 2006;129(4):469. e1-. e32.

32. Sakuma Y., Li Z., Pilbeam C.C., Alander C.B., Chikazu D., Kawaguchi H., Raisz L.G. Stimulation of cAMP production and cyclooxygenase- 2 by prostaglandin E 2 and selective prostaglandin receptor agonists in murine osteoblastic cells. Bone 2004;34(5):827-834.

33. Itonaga I., Sabokbar A., Neale S.D., Athanasou N.A. 1, 25-Dihydroxyvitamin D 3 and prostaglandin E 2 act directly on circulating human osteoclast precursors. Biochem Biophys Res Commun 1999;264(2):590-595.

34. Magnusson P., Hager A., Larsson L. Serum osteocalcin and bone and liver alkaline phosphatase isoforms in healthy children and adolescents. Pediatr Res 1995;38(6):955-961.

35. Brennan P., Thomas G., Langdon J. The role of nitric oxide in oral diseases. Arch Oral Biol 2003;48(2):93-100.

36. D'Attillio M., Di Maio F., D'Arcangela C., Rita Filippi M., Felaco M., Lohinai Z., Festa F., Perinetti G. Gingival endothelial and inducible nitric oxide synthase levels during orthodontic treatment: a cross-sectional study. Angle Orthod 2004;74(6):851-858.

37. Zhang F., Richards L., Angel M.F., Zhang J., Liu H., Dorsett-Martin W. Accelerating flap maturation by vascular endothelium growth factor in a rat tube flap model. Br J Plast Surg 2002;55(1):59-63.

38. Kohno S., Kaku M., Kawata T., Fujita T., Tsutsui K., Ohtani J., Tenjo K., Tohma Y., Motokawa M., Shigekawa M., Kamada H., Tanne K. Neutralizing effects of an antivascular endothelial growth factor antibody on tooth movement. Angle Orthod 2005;75(5):797-804.

39. Graziani F., Ivanovski S., Cei S., Ducci F., Tonetti M., Gabriele M. The in vitro effect of different PRP concentrations on osteoblasts and fibroblasts. Clin Oral Implants Res 2006;17(2):212-219.

40. Peerbooms J.C., Colaris J.W., Hakkert A.A., Van Appeldorn M., Gruijn D.J., Den Oudsten BL, Gosens T. No positive bone healing after using platelet rich plasma in a skeletal defect. An observational prospective cohort study. Int Orthop 2012;36(10):2113-2119.

41. Lems W., Jacobs J., Van Rijn H., Bijlsma J. Changes in calcium and bone metabolism during treatment with low dose prednisone in young, healthy, male volunteers. Clin Rheumatol 1995;14(4):420-424.

42. Reeve J., Zanelli J.M. Parathyroid hormone and bone. Clin Sci 1986;71(3):231238.

43. Madan M.S., Liu Z.J., Gu G.M., King G.J. Effects of human relaxin on orthodontic tooth movement and periodontal ligaments in rats. Am J Orthod Dentofacial Orthop 2007;131(1):8. e1-8. e10.

44. McGorray S.P., Dolce C., Kramer S., Stewart D., Wheeler T.T. A randomized, placebo-controlled clinical trial on the effects of recombinant human relaxin on tooth movement and shortterm stability. Am J Orthod Dentofacial Orthop 2012;141(2):196203. 
45. Rodan G.A., Bourret L.A., Norton L.A. DNA synthesis in cartilage cells is stimulated by oscillating electric fields. Science 1978;199(4329):690-692.

46. Lavine L., Lustrin I., Rinaldi R., Shamos M. Clinical and ultrastructural investigations of electrical enhancement of bone healing. Ann N Y Acad Sci 1974;238(1):552-563.

47. Karanth H., Shetty K. Orthodontic tooth movement and bioelectricity. Indian J Dent Res 2000;12(4):212-221.

48. Stark T.M., Sinclair P.M. Effect of pulsed electromagnetic fields on orthodontic tooth movement. Am J Orthod Dentofacial Orthop 1987;91(2):91-104.

49. Darendeliler M.A., Zea A., Shen G., Zoeliner H. Effects of pulsed electromagnetic field vibration on tooth movement induced by magnetic and mechanical forces: a preliminary study. Aust Dent J 2007;52(4):282-287.

50. Showkatbakhsh R., Jamilian A., Showkatbakhsh M. The effect of pulsed electromagnetic fields on the acceleration of tooth movement. World J Orthod 2010;11(4):e52-e56

51. Spadari G.S., Zaniboni E., Vedovello S.A., Santamaria M.P., do Amaral M.E., Dos Santos G.M., Esquisatto M.A., Mendonca F.A., Santamaria M.Jr Electrical stimulation enhances tissue reorganization during orthodontic tooth movement in rats. Clin Oral Investig 2017;21(1):111-120.

52. Krishtab S., Doroshenko S., Liutik G. Use of vibratory action on the teeth to accelerate orthodontic treatment. Stomatologia (Mosk) 65:61-63, 1986.

53. Ohmae M., Saito S., Morohashi T., Qu H., Seki K., Kurabayashi H. Biomechanical acceleration of experimental tooth movement by ultrasonic vibration in vivopart 1: Homo-directional application of ultrasonication to orthodontic force. Orthod Waves 2001;60:201-212.

54. Nishimura M., Chiba M., Ohashi T., Sato M., Shimizu Y., Igarashi K., Mitani H. Periodontal tissue activation by vibration: intermittent stimulation by resonance vibration accelerates experimental tooth movement in rats. Am J Orthod Dentofacial Orthop 2008;133(4):572-583.

55. Miles P., Smith H., Weyant R., Rinchuse D.J. The effects of a vibrational appliance on tooth movement and patient discomfort: a prospective randomised clinical trial. Aust Orthod J 2012;28(2):213.

56. Leethanakul C., Suamphan S., Jitpukdeebodintra S., Thongudomporn U., Charoemratrote C. Vibratory stimulation increases interleukin-1 beta secretion during orthodontic tooth movement. Angle Orthod 2015;86(1):74-80.

57. Liao Z., Elekdag-Turk S., Turk T., Grove J., Dalci O., Chen J., Zheng K., Darendeliler M.A., Swain M., Li Q. Computational and clinical investigation on the role of mechanical vibration on orthodontic tooth movement. $J$ Biomech 2017; 60:57-64.

58. Altan A.B. Ortodontide lazer uygulamaları. Turkiye Klinikleri Journal of Orthodontics-Special Topics 2015;1(1):4249.

59. Eells J.T., Wong-Riley M.T., VerHoeve J., Henry M., Buchman E.V., Kane M.P., Gould L.J., Das R., Jett M., Hodgson B.D., Margolis D., Whelan H.T. Mitochondrial signal transduction in accelerated wound and retinal healing by near-infrared light therapy. Mitochondrion 2004;4(5):559-567. 60. Kawasaki K., Shimizu N. Effects of lowenergy laser irradiation on bone remodeling during experimental tooth movement in rats. Lasers Surg Med 2000;26(3):282-291.

61. Cruz D.R., Kohara E.K., Ribeiro M.S., Wetter N.U. Effects of low intensity laser therapy on the orthodontic movement velocity of human teeth: A preliminary study. Lasers Surg Med 2004;35(2):117-120.

62. Youssef M., Ashkar S., Hamade E., Gutknecht N., Lampert F., Mir M. The effect of low-level laser therapy during orthodontic movement: a preliminary study. Lasers Med Sci 2008;23(1):27-33.

63. Doshi-Mehta G., Bhad-Patil W.A. Efficacy of low-intensity laser therapy in reducing treatment time and orthodontic pain: a clinical investigation. $A m$ J Orthod Dentofacial Orthop 2012;141(3):289-297.

64. da Silva Sousa M.V., Scanavini M.A., Sannomiya E.K., Velasco L.G., Angelieri F. Influence of low-level laser on the speed of orthodontic movement. Photomed Laser Surg 2011;29(3):191-196.

65. Limpanichkul W., Godfrey K., Srisuk N., Rattanayatikul C. Effects of low level laser therapy on the rate of orthodontic tooth movement. Orthod Craniofac Res 2006;9(1):38-43. 
66. Goulart C.S., Nouer P.R..A., Mouramartins L, Garbin I.U., Lizarelli Rd.F.Z. Photoradiation and orthodontic movement: experimental study with canines. Photomed Laser Surg 2006;24(2):192-196.

67. de Almeida V.L., de Andrade Gois V.L., Andrade R.N., Cesar C.P., de AlbuquerqueJunior R.L., de Mello Rode S., Paranhos L.R. Efficiency of low-level laser therapy within induced dental movement: A systematic review and meta-analysis. $J$ Photochem Photobiol B 2016;158:258-266.

68. Sonesson M., De Geer E., Subraian J., Petrén S. Efficacy of low-level laser therapy in accelerating tooth movement, preventing relapse and managing acute pain during orthodontic treatment in humans: a systematic review. BMC Oral Health 2016;17(1):11.

69. Wong-Riley M.T., Liang H.L., Eells J.T., Chance B., Henry M.M., Buchmann E., Kane M., Whelan H.T. Photobiomodulation Directly Benefits Primary Neurons Functionally Inactivated by Toxins. Role of Cytochrome c oxidase. J Biol Chem 2005;280(6):4761-4771.

70. Ekizer A., Uysal T.., Güray E, Akkuş D. Effect of LED-mediated-photobiomodulation therapy on orthodontic tooth movement and root resorption in rats. Lasers Med Sci 2015;30(2):779-785.

71. Kau C.H., Kantarci A., Shaughnessy T., Vachiramon A., Santiwong P., de la Fuente A., Skrenes D., Ma D., Brawn P. Photobiomodulation accelerates orthodontic alignment in the early phase of treatment. Prog Orthod 2013;14:30.

72. Ekizer A., Türker G., Uysal T., Güray E., Taşdemir Z. Light emitting diode mediated photobiomodulation therapy improves orthodontic tooth movement and miniscrew stability: A randomized controlled clinical trial. Lasers Surg Med 2016;48(10):936-943. 73. Nahas A.Z., Samara S.A., Rastegar-Lari T.A. Decrowding of lower anterior segment with and without photobiomodulation: a single center, randomized clinical trial. Lasers Med Sci 2017;32(1):129-135. 